\title{
Belgeo
}

Revue belge de géographie

\section{Editorial: Cities and Sustainable Development}

\section{Stefan De Corte}

\section{(2) OpenEdition}

\section{Journals}

Electronic version

URL: http://journals.openedition.org/belgeo/16070

DOI: 10.4000/belgeo.16070

ISSN: 2294-9135

\section{Publisher:}

National Committee of Geography of Belgium, Société Royale Belge de Géographie

\section{Printed version}

Date of publication: 30 December 2002

Number of pages: $315-318$

ISSN: 1377-2368

\section{Electronic reference}

Stefan De Corte, "Editorial: Cities and Sustainable Development", Belgeo [Online], 4 | 2002, Online since 31 December 2002, connection on 11 February 2021. URL: http://journals.openedition.org/belgeo/ 16070 ; DOI: https://doi.org/10.4000/belgeo.16070

This text was automatically generated on 11 February 2021.

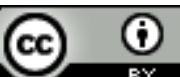

Belgeo est mis à disposition selon les termes de la licence Creative Commons Attribution 4.0 International. 


\title{
Editorial: Cities and Sustainable Development
}

\author{
Stefan De Corte
}

1 In this special issue of Belgeo we brought together several articles on Cities and Sustainable Development.

2 Two contributions focus on specific urban case studies. In her article «The Social Sustainability of Multicultural Cities: a neighbourhood affair?», Annick Germain uses the case of the city of Montréal (Canada) to argue that social and cultural diversity should be at the centre of our attention if we think about sustainable development in an urban context. Using the findings of two of her research projects she explores the modes of coexistence in seven multiethnic neighbourhoods in Montréal focusing on community organisations and on the social interaction in public space. This comparative research leads her to conclude that «ethnocultural diversity seems to depolarize relations between ethnic groups». The challenge then lies in the management of this diversity at the neighbourhood level. She analyses this in the last part of her contribution through the provision of recreation services and sports in several municipalities in the Montréal Area. Although the neighbourhood seems to be pivotal in building an inclusive city, the author concludes with some critical remarks on the neighbourhood concept.

In his article «Les impacts sociaux de la rénovation urbaine à Bruxelles: analyse des migrations intra-urbaines», Mathieu Van Criekingen explores the link between urban renewal in Brussels, the social transformation of neighbourhoods and sustainable social development. He uses an innovative method to exploit census data at neighbourhood level to get a detailed insight into the intra-urban migration pattern of Brussels. By focusing on certain areas that have experienced strong transformations in the recent past, he is able to analyse the characteristics of the population that is "pushed out» of these neighbourhoods, and to compare them with the demographic and socialeconomic characteristics of the replacement population. His research produces a detailed geography of the flows of migration within the city limits providing additional 
evidence that urban renewal often leads to heightened concentration of socially weaker residents in deprived neighbourhoods.

4 Two other contributions have the urbanisation of Belgium as their topic. The contribution by Olivier Dubois focuses on the production of new housing and the characteristics of the built environment in Belgium («Stratégies des acteurs de la construction résidentielle neuve et caractéristiques des espaces bâtis en Belgique»). By analysing the different actors involved in the production of new housing he gives us an insight in the logic behind the extensive urban sprawl which is characteristic for Belgium and which is considered to be unsustainable. In his article he provides us with an interesting screening of these different actors: the commissioners of new housing (maitre d'oeuvre), the market of vacant building plots, the mortgage system, the role of the architect, the building process and the role of the state. He explains how their strategies through time have resulted in a residential market that is dominated by private capital, small entrepreneurs and suburban single-family housing. By critically examining the role of the State he shows its responsibility in the production of urban sprawl. It is argued that only by understanding the structures, processes and motives which guide today's mode of urbanisation in Belgium that we can counter its unsustainable outcome.

5 Halleux, Brück and Mairy analyse the urban sprawl in Belgium from a European perspective («La périurbanisation résidentielle en Belgique à la lumière des contextes suisses et danois: enracinement, dynamiques centrifuges et régulations collectives»). They examine the land-use planning, the housing policy and the transport development in Belgium in comparison with other European countries, with special attention to Denmark and Switzerland (two countries which are considered to be successful in containing urban sprawl). The history and modes of land use planning in Belgium are analysed in the light of the ideological underpinnings of the planning system. The authors make a convincing argument that the market-oriented attitude towards land-ownership and planning leads to weak regulation practices and lies at the heart of the extensive urban sprawl in Belgium. They develop this argument in contrast with the Danish and Swiss case. A second important issue which the authors develop is housing. Since long Belgium has known an attitude and policy towards housing that can be considered anti-urban, that favours private-ownership and that promotes single-family housing. This has produced a housing-market that by its structure and spatial configuration is held responsible for a high degree of urban sprawl. In the last part of the contribution the importance of transport policy is examined, comparing the car-centred development in Belgium with that of the more public transport based developments in Switzerland and Denmark.

Enjoy this issue. 


\section{AUTHOR}

\section{STEFAN DE CORTE}

Cosmopolis (City, Culture \& Society), Geografisch Instituut, Vrije Universiteit Brussel, stefan.de.corte@vub.ac.be 